\title{
Safe harbor
}

\author{
Michael Maddaus, MD
}

From the Department of Surgery, University of Minnesota, Minneapolis, Minn.

Received for publication Sept 13, 2002; accepted for publication Oct 1, 2002.

Address for reprints: Michael Maddaus, MD, Associate Professor of Surgery, Department of Surgery, University of Minnesota, 420 Delaware St, Box 207, Minneapolis, $\quad$ MN $55455 \quad$ (E-mail: madda001@umn.edu).

J Thorac Cardiovasc Surg 2003;125:454-5

Copyright $\odot 2003$ by The American Association for Thoracic Surgery

0022-5223/2003 $\$ 30.00+0$

doi:10.1067/mtc.2003.294

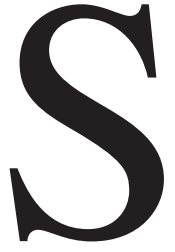

urgical dogma has a legitimate role in preventing us from performing operations we should not perform. It defines, often helpfully, the rules of surgical engagement. Break the rules, and your patient may suffer.

One example of dogma is that lobectomy with mediastinal lymph node dissection should be performed for all clinical stage I non-small cell lung cancers. ${ }^{1}$ A strict rule such as this places us in a safe harbor, obviating any worry about variables like tumor biology, presence or absence of nodal disease, and pulmonary resection margins. These elements of surgical decision making are rendered moot. After all, the prescribed operation automatically covers all the bases.

At the other extreme, some surgeons may defy dogma and, instead, do what is easier. For instance, just go ahead with a VATS (video-assisted thoracoscopic surgery) wedge resection without lymph node sampling, especially after negative mediastinoscopic results. From this vantage point, intralobar and interlobar lymph node removal may be unimportant for survival. After all, tumor biology probably plays the primary role in prognosis, so simple tumor excision should suffice.

Thankfully, an alternative middle road may be developing in thoracic surgical oncology, as it has in other areas of surgical oncology such as breast cancer and melanoma. In those two areas, less surgery has become more common. The reasons include (1) ability to assess resection margins intraoperatively for tumor presence, (2) technical advances such as sentinel node biopsy with immunohistochemical and polymerase chain reaction detection of occult micrometastases, and (3) scientific evidence that survival is equivalent to that of more radical procedures.

In the January 2003 issue of the Journal, Higashiyama and associates ${ }^{2}$ showed us how to be sure that the "margins are negative" intraoperatively, through a unique method of washing, in $200 \mathrm{~mL}$ of saline solution, the staple cartridges (if staplers are used); the wedge specimen itself (if an Nd:YAG laser or electric scissors are used); or both (if both techniques are used). Then, centrifugal plating with a Cytospin device (Thermo Electron Corporation, Waltham, Mass) is performed, with examination of the stained slides for evidence of tumor cells. The entire process takes only 20 to 25 minutes.

In their study, of 115 lesions resected (110 via open thoracotomy with wide wedge resection or segmentectomy), 11 (10\%) had positive surgical resection margins. Margin positivity correlated with tumor size: less than $1.0 \mathrm{~cm}, 3 \%(1 / 35)$; 1.1 to $2.0 \mathrm{~cm}, 8 \%(3 / 36) ; 2.1$ to $3.0 \mathrm{~cm}, 14 \%(4 / 28)$; and more than $3.1 \mathrm{~cm}, 23 \%$ (3/13). Margin positivity rates did not differ by resection technique. Of the 11 patients with positive margins, 7 could not undergo further surgical resection because of limited physiologic reserve; of these 7 patients, 3 experienced recurrence in their "surgical resection margin." Most noteworthy was that the finding of a negative margin was highly predictive: 0 margin recurrences in 101 resected specimens.

I have never found the rationale for segmentectomy or wedge resection via thoracotomy in a patient with sufficient pulmonary reserve for lobectomy to be compelling. The gain in preservation of pulmonary function (as compared with lobectomy) is likely to be so small that it does not warrant the potential risks of a higher local recurrence rate or of death from cancer. ${ }^{3}$ However, a limited VATS resection, avoiding the immediate morbidity of a thoracotomy, has appeal—if proper cancer staging can be accomplished and if the surgeon is sure that the 
resection is complete, that is, that the "margins are negative." In a protocol setting, I could envision performing a limited VATS wedge resection for stage IA tumors as primary therapy in a patient physiologically able to undergo lobectomy, by using thoracoscopic sentinel node sampling ${ }^{4}$ combined with the margin testing technique of Higashiyama and colleagues. ${ }^{2}$

However, until definitive data are available, I continue to stay in the safe harbor of lobectomy and nodal resection.

Before venturing from this safe harbor, either intentionally in a patient with good cardiopulmonary reserve or as a compromise operation in a patient unable to tolerate lobectomy, we must first protect the patient. Higashiyama and associates $^{2}$ have now provided us with one piece of the limited resection safety puzzle with their technique of margin testing. Until now, our ability to assess margins by frozen section has been severely limited by the use of staples or by the difficulty of accurately dissecting and freezing an open pulmonary margin. The technique pro- vided by Higashiyama's group ${ }^{2}$ should be adopted and used by all surgeons performing a limited resection, regardless of the indication.

\section{References}

1. Martini N, Bains MS, Burt ME, Zakowski MF, McCormack P, Rusch VW, et al. Incidence of local recurrence and second primary tumors in resected stage I lung cancer. J Thorac Cardiovasc Surg. 1995;109: $120-29$.

2. Higashiyama M, Kodama K, Takami K, Higaki N, Nakayama T, Yokouchi $\mathrm{H}$. Intraoperative lavage cytologic analysis of surgical margins in patients undergoing limited surgery for lung cancer. $J$ Thorac Cardiovasc Surg. 2003:125:101-7.

3. Ginsberg RJ, Rubinstein LV. Randomized trial of lobectomy versus limited resection for T1 N0 non-small cell lung cancer. Ann Thorac Surg. 1995;60:615-22.

4. Nomori H, Horio H, Naruke T, Orikasa H, Yamazaki K, Suemasu K. Use of technetium-99m tin colloid for sentinel lymph node identification in non-small cell lung cancer. J Thorac Cardiovasc Surg. 2002;124:486-92.

\section{JTCVS On-Line Manuscript Submission and Review \\ Please visit http://www.editorialmanager.com/jtcvs/}

Effective September 15, 2001, authors and reviewers may submit manuscripts and reviews electronically via Editorial Manager, our new Web-based system with full electronic submission, review, and status update capabilities.

As we move from paper to electronic submissions, the Editorial Office will make proxy submissions of all manuscripts accompanied by a diskette containing the electronic files of the text, tables, and figures. Editors, authors, and reviewers will receive automatic e-mails when significant events occur.

We strongly encourage all authors and reviewers to use Editorial Manager. Although we will continue to accommodate the submission of paper manuscripts for some months, our goal is to be completely electronic within 9 to 12 months.

All individuals currently in our database for whom we have e-mail addresses will receive via e-mail a system-assigned username and password that can be used to log in to the system without prior registration. All those not receiving the e-mail must register the first time they use the system.

As with any broad systemic change, the conversion to the new system will take some time to complete. We ask your patience as we replace our in-office database with the new system. We also encourage you to take advantage of the speed and efficiency that the new system will provide for us all: editor, author, reviewer, and publisher. 